\title{
Analisis Kemampuan Pemahaman Konsep Mahasiswa dalam Menyelesaikan Soal Persamaan Diferensial Ditinjau dari Gaya Kognitif
}

\author{
Ayu Tsurayya ${ }^{1}$, Nur Jannah Kurnianingrum ${ }^{2}$ \\ 1, 2 Program Studi Pendidikan Matematika, FKIP Universitas Muhammadiyah Prof. Dr. HAMKA \\ J1. Tanah Merdeka, Rambutan, Kec. Ciracas, Kota Jakarta Timur \\ ayu.tsurayya@uhamka.ac.id
}

\begin{abstract}
Concept understanding is a basic ability that must be possessed by students before solving a mathematical problem. This article aims to describe students' conceptual understanding abilities in solving differential equations in terms of cognitive style. This research was conducted at FKIP Muhammadiyah University Prof. Dr. Hamka with the research subject of 364 th semester mathematics education students who are taking differential equations courses. The research method uses a qualitative descriptive approach. Data were collected through tests and interviews. The first test instrument is using the GEFT test (Group Embedded Figure Test) and a concept understanding test. Where the results of this study the percentage of the ability to understand the concept as a whole $46.50 \%$ which is still relatively low. In the level of concept understanding, the high category is $25 \%$, the medium category is $61.11 \%$ and the low category is $13.89 \%$. If we look at the indicators, the percentage of achievements that have reached both I1, I3 and I4 and indicators I2, I5, I6 and I7 are still in the low category. The ability to understand concepts in the high category is found in the FI cognitive style, both FIK and FIL, the medium and low categories belong to the FIL to FDL cognitive style.

Keywords: Understanding Matematical Concept, Differential Equations, Cognitive Style (Field Dependence dan Field Independence)
\end{abstract}

\begin{abstract}
Abstrak
Pemahaman konsep merupakan kemampuan dasar yang harus dimiliki mahasiswa sebelum menyelesaikan suatu permasalahan matematika. Artikel ini bertujuan untuk mendeskripsikan kemampuan pemahaman konsep mahasiswa dalam menyelesaikan soal persamaan diferensial ditinjau dari gaya kognitif. Penelitian ini dilakukan di FKIP Universitas Muhammadiyah Prof. Dr. Hamka dengan subjek penelitian 36 mahasiswa pendidikan matematika semester 4 yang sedang mengikuti mata kuliah persamaan diferensial. Metode penelitian menggunakan pendekatan deskriptif kualitatif. Data dikumpulkan melalui tes dan wawancara. Instrumen tes yang pertama yaitu menggunakan tes GEFT (Group Embedded Figure Test) dan tes pemahaman konsep. Dimana hasil penelitian ini persentase kemampuan pemahaman konsep secara keseluruhan 46,50\% dimana masih tergolong rendah. Dalam tingkat pemahaman konsepnya, kategori tinggi 25\%, kategori sedang 61,11\% dan kategori rendah 13,89\%. Jika dilihat perindikator presentase pencapaian yang sudah mencapai baik untuk indikator I1, I3 dan I4 dan indikator I2, I5, I6 dan I7 masih dalam kategori rendah. Kemampuan pemahaman konsep kategori tinggi terdapat pada gaya kognitif FI baik FIK maupun FIL, kategori sedang dan rendah dimiliki gaya kognitif FIL sampai FDL.

Kata kunci: Pemahaman Konsep Matematika, Persamaan Diferensial dan Gaya Kognitif (Field Dependence dan Field Independence)
\end{abstract}

Copyright (c) 2021 Ayu Tsurayya, Nur Jannah Kurnianingrum

$\triangle$ Corresponding author: Nur Jannah Kurnianingrum

Email Address: nurjanahkurnia24@gmail.com (J1. Tanah Merdeka, Rambutan, Kec. Ciracas, Kota Jakarta Timur)

Received 13 July 2021, Accepted 21 July 2021, Published 06 August 2021

\section{PENDAHULUAN}

Persamaan diferensial merupakan mata kuliah yang harus diikuti mahasiswa program studi pendidikan matematika di perguruan tinggi salah satunya di FKIP Universitas Muhammadiyah Prof. Dr. Hamka. Dalam pengertiannya persamaan diferensial adalah persamaan gabungan dari fungsi yang tidak diketahui turunannya (Sihombing \& Dahlia, 2018). Pada persamaan diferensial jika terdapat satu atau lebih 
turunan dari suatu variabel terhadap variabel lain maka variabel pertama disebut variabel dependen dan variabel yang kedua disebut variabel independen (Suningsih \& Nopitasari, 2020). Persamaan diferensial dibagi menjadi persamaan diferensial biasa dan persamaan diferensial parsial dimana persamaan diferensial biasa memiliki satu variabel bebas sedangkan persamaan diferensial parsial memiliki lebih dari satu variabel bebas.

Persamaan diferensial memuat konsep turunan dan integral dimana sebelumnya mahasiswa sudah mendapatkan konsep ini pada mata kuliah kalkulus diferensial dan kalkulus integral. Ketika mahasiswa sudah menguasai konsep turunan dan integral mereka dapat menentukan cara yang tepat dalam menyelesaikan soal yang dikerjakan. Dan sebaliknya jika mahasiswa tidak dapat menguasai pemahaman konsep pada materi turunan dan integral akan terjadinya kemungkinan lebih besar kesalahan dalam penyelesaiannya. Sehingga di dalam matematika pemahaman menjadi unsur yang mendasar untuk mempelajari matematika secara bermakna (Utami et al., 2020). Permendiknas Nomor 22 Tahun 2006 menyebutkan salah satu kemampuan yang penting dalam pembelajaran matematika adalah kemampuan pemahaman konsep matematis (Gusmania \& Agustyaningrum, 2020).

Pemahaman konsep menurut (Aydin Ceran \& Ates, 2020) jika individu sudah mampu memikirkannya, menggunakan itu di bidang lain selain yang mereka sedang pelajari, menyatakannya menggunakan kalimat sendiri, menemukan metafora atau analogi serta membangun model mental dan fisiknya. Menurut sumarmo (1987) menyebutkan bahwa terdapat dua jenis pemahaman konsep yaitu pemahaman instrumental dan pemahaman rasional (Utami et al., 2020). Dimana pemahaman instrumental merupakan pemahaman konsep yang saling terpisah dan terdapat rumus yang dihafal untuk menghitung perhitungan matematika yang sederhana. Pemahaman rasional menggunakan perumusan yang lebih terstruktur dalam menyelesaikan permasalahan matematika yang lebih luas. Penguasaan konsep dan prinsip dalam matematika sebagai syarat awal keberhasilan belajar matematika untuk melanjutkan ke tahap yang lebih tinggi, karena dalam matematika konsep sederhana keterhubungan dengan konsep matematika yang lebih kompleks. Sehingga pemahaman konsep merupakan kemampuan yang dimiliki individu secara mendalam dalam memahami suatu topik tertentu sehingga dapat mengungkapkan kembali dalam kalimatnya, mampu mengaplikasikannya ke dalam konsep yang sesuai dan mampu menyampaikannya dalam bentuk yang lebih mudah dimengerti baik pemahaman instrumental maupun pemahaman rasional.

Menurut sebuah observasi penelitian terhadap kemampuan persamaan diferensial yang ditemukan (Haswati \& Dian Nopitasari, 2019) bahwa kemampuan mahasiswa masih relatif rendah, dimana disebabkan pada kurangnya pemahaman konsep yang mendasar pada turunan dan integral. Selain itu, penelitian (Suningsih \& Nopitasari, 2020) menyebutkan bahwa mahasiswa cenderung menghafal konsep yang diberikan pendidik tanpa pemahaman maksud dan isinya. Mahasiswa merupakan peserta didik yang memiliki kedudukan tertinggi dalam dunia jenjang pendidikan.

Mahasiswa memiliki kecenderungan gaya belajar yang sudah terbentuk dari cara individu memahami sesuatu yang didapat dan cara berpikir yang konsisten setiap waktu (Umah \& Vitantri, 2019). 
Hal ini dapat dilihat dari gaya belajar mereka, terdapat mahasiswa yang hanya membaca saja dapat langsung memahami konsepnya, ada mahasiswa yang harus mengulang-ulang dengan latihan soal baru memahami konsepnya, selain itu ada mahasiswa yang harus mencatat terlebih dahulu baru memahami konsepnya, ada juga yang hanya mendengarkan saja dapat memahami konsepnya, hal ini ditinjau dari segi gaya belajar. Gaya belajar mempengaruhi perbedaan diri seseorang dalam segi menyusun, mengumpulkan informasi, mengolah informasi dan pengalaman-pengalaman yang didapatkan untuk diterapkan. Perbedaan dalam gaya belajar disebut dengan gaya kognitif (Wulandari \& Muhandar, 2019).

Gaya kognitif dalam aspek psikologis dibagi menjadi dua, yaitu gaya kognitif field dependent dan gaya kognitif field independent. Dimana dua konsep gaya kognitif Field Independence (FI) dan gaya kognitif Field Independence (FI) berasal dari studi lapangan tentang persepsi oleh psikolog dari Amerika yaitu H.A Witkin (Yin, 2020). Menurut Slameto (1988) individu dengan gaya kognitif field independent mengarah untuk menyatakan suatu gambaran terlepas dari latar belakang gambaran tersebut dan lingkungan tidak mempengaruhinya serta dapat membedakan objek-objek dari konteks sebenarnya, sedangkan individu dengan gaya kognitif field dependent sebaliknya (Andriyani \& Ratu, 2018). Menurut (Dewi et al., 2019) seseorang yang memiliki gaya kognitif field dependent dalam strategi belajar dan pengembangan restrukur kognitif kurang independent sebaliknya dengan yang memiliki gaya kognitif field independent cenderung lebih independent namun dalam keterampilan komunikasi interpersonal field independent kurang independent berbeda dengan yang field dependent cenderung lebih independent. Sementara menurut (Izzatin et al., 2020) gaya kognitif didefinisikan sebagai pendekatan dan kebiasaan seseorang untuk mengatur dan mewakili informasi yang diperoleh yang kemudian mempengaruhi cara seseorang untuk mempersepsikan dan merespon suatu peristiwa dan ide. Sehingga disimpulkan bahwa gaya kognitif merupakan bagaimana cara seseorang dalam mempersepsikan, memberi instruksi atau isyarat, menyimpan serta mengingat informasi yang didapatkan.

Dari latar belakang tersebut peneliti tertarik untuk melakukan penelitian tentang kemampuan pemahaman konsep mahasiswa dalam menyelesaikan soal persamaan diferensial ditinjau dari gaya kognitif. Dengan adanya perbedaan gaya kognitif akan mempengaruhi perbedaan pendapat dari masingmasing dalam menentukan benar atau salahnya jawaban mahasiswa dalam menjawab soal persamaan diferensial sehingga munculnya perbedaan cara berpikir dan perilaku mahasiswa.

\section{METODE}

Penelitian ini menggunakan pendekatan kualitatif dengan metode deskriptif yang bertujuan untuk mengetahui kemampuan pemahaman konsep mahasiswa dalam menyelesaikan soal persamaan diferensial ditinjau dari gaya kognitif. Subjek dalam penelitian ini adalah 49 orang mahasiswa yang mengambil mata kuliah persamaan diferensial di Program Studi Pendidikan Matematika FKIP Universitas Muhammadiyah Prof. Dr. Hamka. Pengambilan sampel menggunakan teknik sampel acak atau random. Data dikumpulkan melalui test dan wawancara. Instrument test berupa test gaya kognitif dan test pemahaman konsep. 
Test gaya kognitif diberikan dalam bentuk Group Embedded Figures Test (GEFT) yang dikembangkan oleh psikolog dari Amerika yaitu H.A Witkin (Yin, 2020). Tes ini untuk mengelompokkan mahasiswa yang memiliki gaya kognitif field dependent dan gaya kognitif field independent. Pada tes ini mahasiswa diminta untuk menemukan sebuah pola gambar sederhana yang terdapat pada pola gambar yang kompleks. Tes berisi 25 soal dengan bagian awal berisi 7 soal sebagai latihan dimana skor tidak diperhitungkan, bagian kedua dan ketiga masing-masing berisi 9 soal. Jika jawaban benar maka skor yang diberikan 1 dan jawaban salah diberikan skor 0 sehingga skor maksimal adalah 18. Mahasiswa yang mendapatkan skor $\leq 9$ digolongkan FD dan > 9 digolongkan FI (Wulandari \& Muhandar, 2019).

Adapun tes pemahaman konsep berisi soal-soal yang sudah divalidasi dan terdapat 7 indikator pemahaman konsep matematis menurut depdiknas (2006) yaitu: (a) menyatakan ulang sebuah konsep; (b) mengklasifikasikan objek-objek menurut sifat-sifat tertentu (sesuai dengan dengan konsepnya; (c) memberikan contoh dan non-contoh dari konsep; (d) menyajikan konsep dalam berbagai bentuk representasi matematis; (e) mengembangkan syarat perlu atau syarat cukup suatu konsep; (f) menggunakan, memanfaatkan, dan memilih prosedur atau operasi tertentu dan; (g) mengaplikasikan konsep atau algoritma pemecahan masalah (Utari \& Utami, 2019).

Data yang sudah dikumpulkan kemudian dikelompokkan berdasarkan hasil skor tes yang didapatkan mahasiswa dimana diklasifikasikan dalam tabel 1 berikut.

Tabel 1. Interpretasi Persentase Kemampuan Pemahaman Konsep Matematis

\begin{tabular}{|c|c|}
\hline Rentang Skor & Kategori \\
\hline $85,00-100$ & Sangat Baik \\
\hline $70,00-84,99$ & Baik \\
\hline $55,00-69,99$ & Cukup \\
\hline $40,00-54,99$ & Rendah \\
\hline $0,00-39,99$ & Sangat Rendah \\
\hline
\end{tabular}

(Kartika, 2018)

Setelah itu mahasiswa dikelompokkan berdasarkan tingkat pemahaman konsepnya yaitu dibagi menjadi tiga kategori, tinggi, sedang dan rendah. Langkah terakhir pengambilan data yaitu dengan melakukan wawancara dimana hasil wawancara ini untuk memperkuat hasil jawaban mahasiswa. Data hasil tes dan hasil wawancara kemudian digabungkan dan diambil kesimpulan untuk mengetahui kemampuan pemahaman konsep mahasiswa dalam menyelesaikan soal persamaan diferensial ditinjau dari gaya kognitifnya.

\section{HASIL DAN DISKUSI}

Hasil penelitian ini merupakan hasil yang diperoleh mahasiswa dalam menyelesaikan soal persamaan diferensial ditinjau dari gaya kognitif mahasiswa yaitu berdasarkan data dari 36 mahasiswa diperoleh 15 mahasiswa yang tergolong field dependent dan 21 mahasiswa yang tergolong field independent. Adapun hasil kemampuan pemahaman konsep mahasiswa pada tabel 2. 
Tabel 2. Hasil Tes Kemampuan Pemahaman Konsep Matematis

\begin{tabular}{|l|l|l|l|}
\hline Jumlah Mahasiswa & Nilai Maksimal & Nilai Minimum & Rata-rata \\
\hline 36 & 75 & 17 & 46,50 \\
\hline
\end{tabular}

Hasil tes kemampuan pemahaman konsep mahasiswa pada tabel 2 menunjukkan dari 36 mahasiswa diperoleh nilai maksimal 75, nilai minimum 17 dan rata-rata dari keseluruhan nilai adalah 46,50. Selanjutnya untuk memenuhi kategori tinggi, sedang dan rendah kemampuan pemahaman konsep mahasiswa dapat dilihat pada tabel 3 .

Tabel 3. Tingkat Pemahaman Konsep Mahasiswa

\begin{tabular}{|c|l|l|l|}
\hline Kategori & \multicolumn{1}{|c|}{ Ketentuan } & Jumlah Mahasiswa & Persentase \\
\hline Kelompok tinggi & $>60,92$ & 9 & 25 \\
\hline Kelompok sedang & $32,07 \leq$ Nilai $\leq 60,92$ & 22 & 61,11 \\
\hline Kelompok rendah & $<32,07$ & 5 & 13,89 \\
\hline
\end{tabular}

Pada tabel 3 menunjukkan kategori pemahaman konsep mahasiswa dalam menyelesaikan soal persamaan diferensial dimana hasil dari tes pemahaman konsep didapat untuk kategori kelompok tinggi sebesar 25\% sebanyak 9 mahasiswa dengan perolehan nilai lebih dari 60,92 dan kelompok sedang sebesar $61,11 \%$ dengan jumlah 22 mahasiswa yang memperoleh nilai antara kurang dari sama dengan 32,07 dan kurang dari sama dengan 60,92 serta 13,89\% yang termasuk kelompok rendah dengan nilai kurang dari 32,07 sebanyak 5 mahasiswa. Berikut grafik tingkatan pemahaman konsep dilihat dari kategori kelompok tinggi, kelompok sedang dan kelompok rendah.

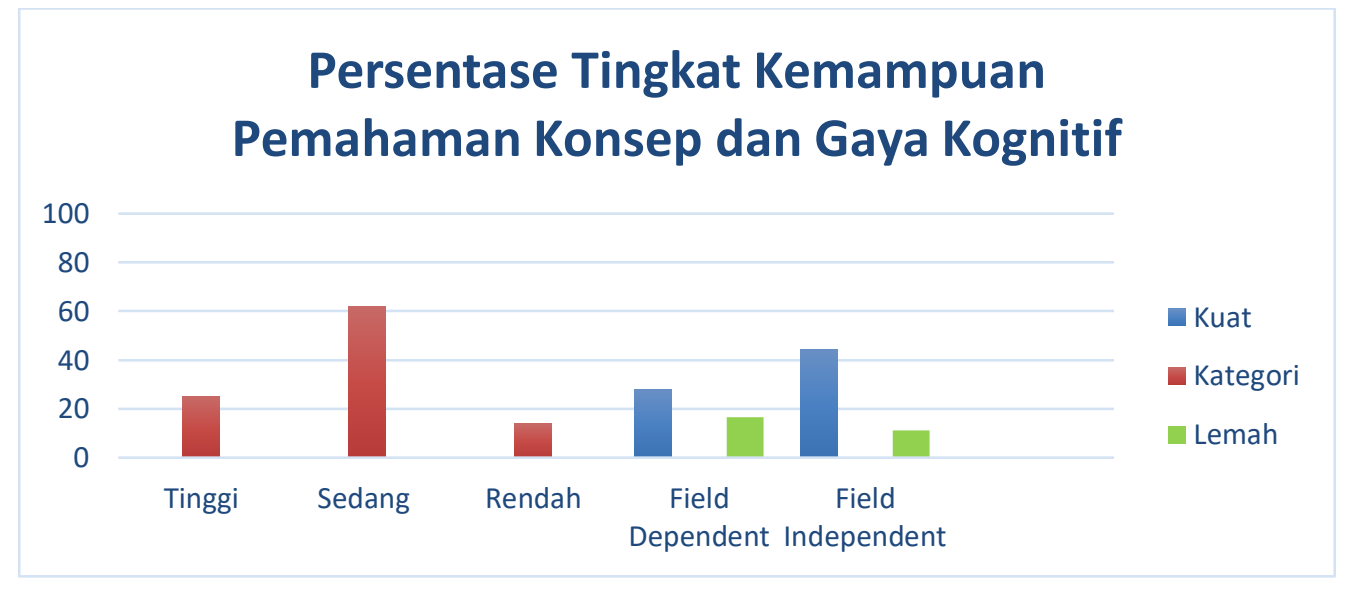

Gambar 1. Grafik Tingkatan Pemahaman Konsep

Untuk mengetahui kemampuan pemahaman konsep mahasiswa ditinjau dari gaya kognitif menggunakan instrument GEFT yang sudah diberikan yaitu dari 36 mahasiswa diperoleh 15 mahasiswa yang tergolong field dependent dan 21 mahasiswa yang tergolong field independent. Dari tes GEFT dipilih masing-masing 2 subjek kategori FD dan FI. Analisis subjek FD meliputi subjek FD kuat dan FD lemah sedangkan subjek FI meliputi FI kuat dan FI lemah.

Hasil pemeriksaan data yang didapatkan dari subjek pada setiap indikator berdasarkan hasil tes dan 
wawancara sebagai berikut.

\section{Menyatakan Ulang Sebuah Konsep}
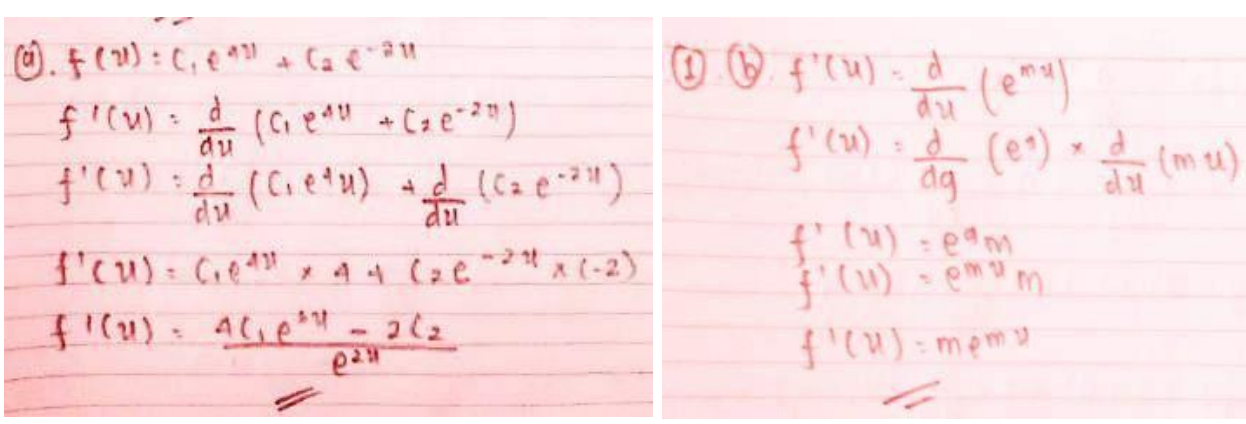

Gambar 2. Hasil dari subjek FDK dan FDL

Berdasarkan gambar 2. Subjek FDK dan FDL untuk nomor 1a hanya mengerjakan turunan $\frac{d y}{d x}$ dan tidak melanjutkan untuk menurunkan turunan dari $\frac{d^{2} y}{d x^{2}}$ serta tidak mensubtitusi kedua turunan untuk membuktikan $\mathrm{f}(\mathrm{x})$ merupakan solusi dari suatu persamaan diferensial. Kemudian untuk $1 \mathrm{~b}$ melakukan yang sama seperti pada 1a.

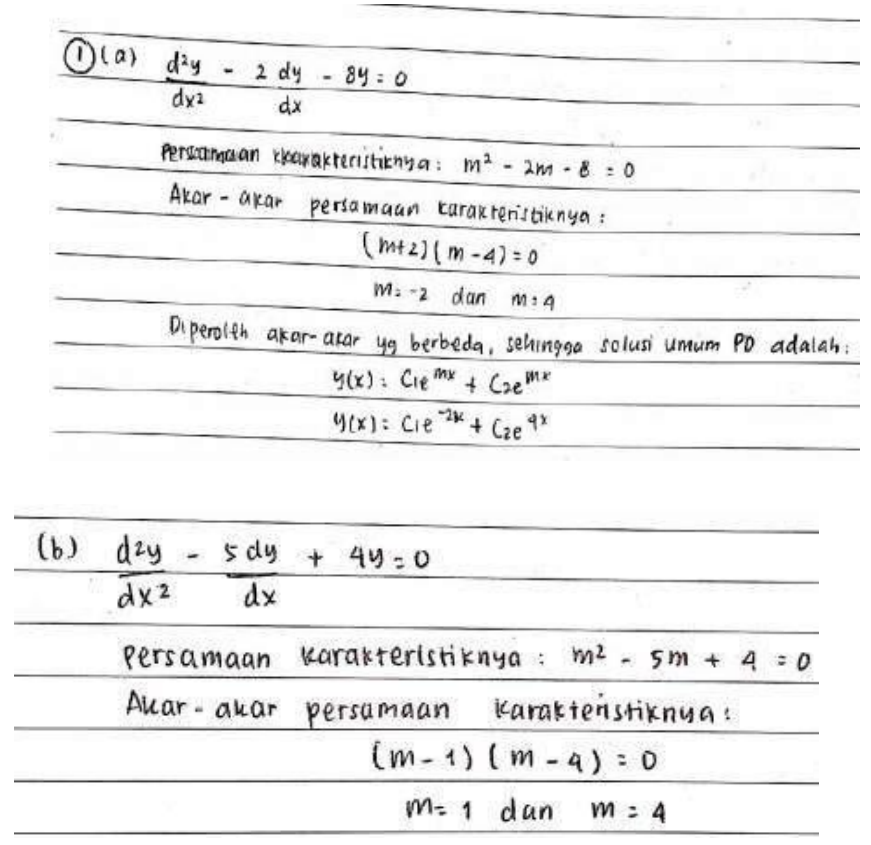

Gambar 3. Hasil dari subjek FIK dan FIL

Berdasarkan pada gambar 3. subjek FIK dan FIL pada indikator menyatakan ulang konsep pada bagian 1a dan $1 \mathrm{~b}$ sudah tepat dalam menentukan metodenya untuk menentukan solusi persamaan diferensial. 


\section{Mengklasifikasikan Objek-Objek Menurut Sifat-Sifat Tertentu}
a. $\left[(x+1) e^{x}-e^{y}\right] d x-x e^{y} d y=0$
b. $\left(4 x^{2} y+3 y\right) d x+\left(x^{4}+1\right) d y=0$
c. $\left(3 x^{2}-2 y^{2}\right) d x+(x y) d y=0$
d. $x^{4} d y+\left(2 x^{3} y-1\right) d x=0$
e. $y^{\prime}+\frac{y}{x}=-x y^{2}$

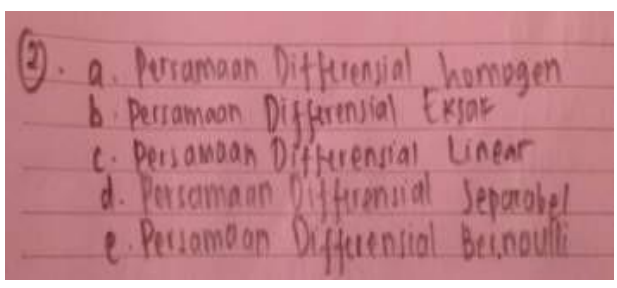

Gambar 4. Hasil dari subjek FDK dan FDL

Berdasarkan pada gambar 4. Subjek FDK dan FDL dalam mengklasifikasikan jenis- jenis persamaan diferensial masih belum tepat dan tidak menjelaskan alasan persamaan diferensial tersebut masuk ke dalam jenisnya karena dalam membedakannya subjek masih ragu untuk menentukan jenisnya dan kurang memahami perbedaan setiap jenis persamaan diferensial.

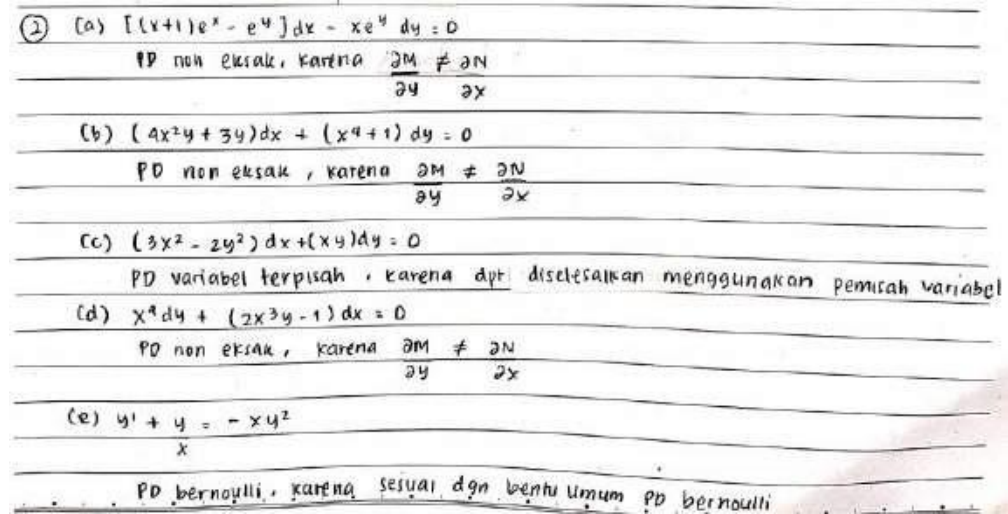

Gambar 5. Hasil dari subjek FIK

Berdasarkan pada gambar 5. Subjek FIK dalam mengklasifikasikan jenis-jenis persamaan diferensial masih terdapat yang belum tepat namun subjek FIK menjelaskan alasan jenis persamaan diferensialnya dan untuk jenis-jenis persamaan diferensialnya subjek FIK dan FIL hanya mengetahui beberapa jenis. Untuk subjek FIL cara mengerjakannya sama seperti FDK dan FDL.

\section{Memberikan Contoh dan Non-Contoh Dari Konsep}
a. $\frac{a y}{d x}+4 x y=2 e^{2 x}$
b. $\frac{\partial v}{\partial x}+\frac{\partial v}{\partial t}-2 v=0$
c. $\frac{d^{2} y}{d x^{2}}-\frac{d y}{d x}-3 y=\sin x$
d. $\frac{\partial^{2} u}{\partial x^{2}}+\frac{\partial^{2} u}{\partial y^{2}}+\frac{\partial^{2} v}{\partial z^{2}}=0$
e. $y d y-x y d x=0$

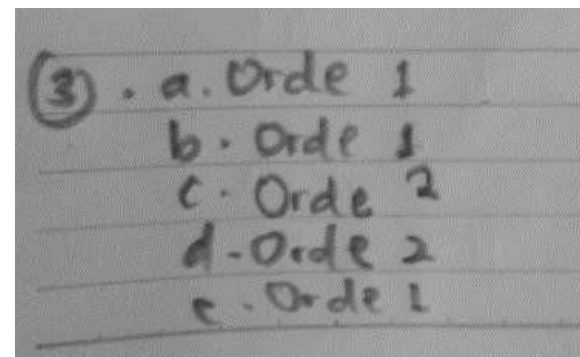

Gambar 6. Hasil dari subjek FDK dan FDL

Berdasarkan pada gambar 6. Subjek FDK dan FDL hanya menuliskan orde-n nya namun tidak menuliskan contoh dan non contoh PDB atau PDP nya. 

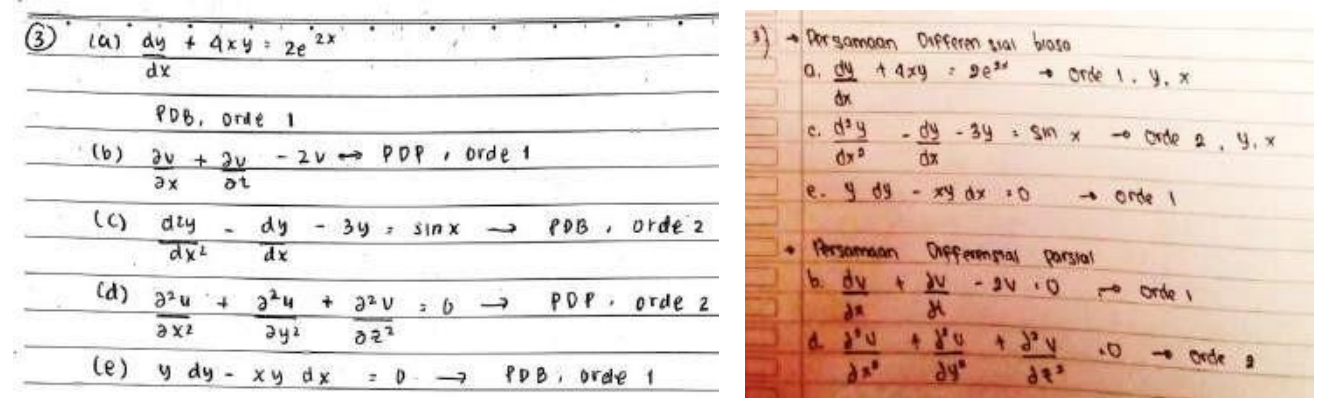

Gambar 7. Hasil dari subjek FIK dan FIL

Berdasarkan pada gambar 6. Subjek FIK dan FIL sudah mampu untuk membedakan jenis PDB dan PDP serta sudah tepat untuk menentukan orde-n nya.

\section{Menyajikan Konsep Dalam Berbagai Bentuk Representasi Matematis}

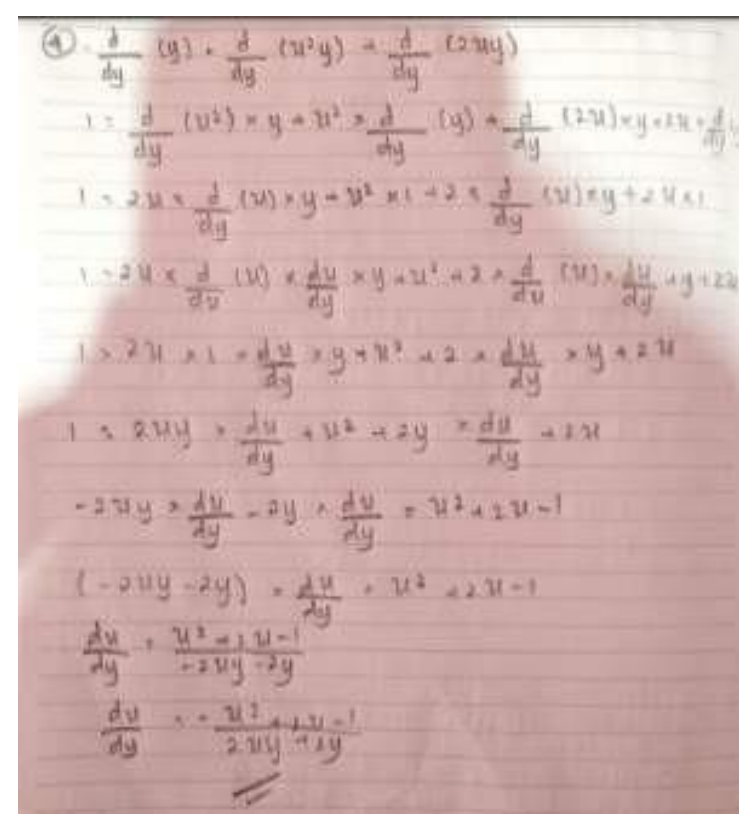

Gambar 8. Hasil dari subjek FDK dan FDL

Berdasarkan pada gambar 8. Subjek FDK dan FDL sudah memisahkan variabelnya, namun dalam prosesnya subjek FDK belum mengintegralkan hasil turunan yang sudah dipisahkan variabelnya dan langsung mensubtitusi nilai syarat awalnya di langkah awal sehingga FDK dan FDL tidak menemukan solusinya. Hal ini FDK dan FDL belum memahami proses untuk menentukan solusi umum persamaan diferensial yang diketahui syarat awalnya dengan menggunakan metode peubah terpisah. Berdasarkan gambar 8. Hasil pekerjaan subjek FIK dan FIL masih belum tepat, pada subjek FIK untuk gambar sebelah kiri belum tepat dalam memisahkan variabel sedangkan FIL sudah tepat memisahkan variabelnya namun kedua subjek dalam mengintegralkan masih belum tepat penyelesaiannya. 

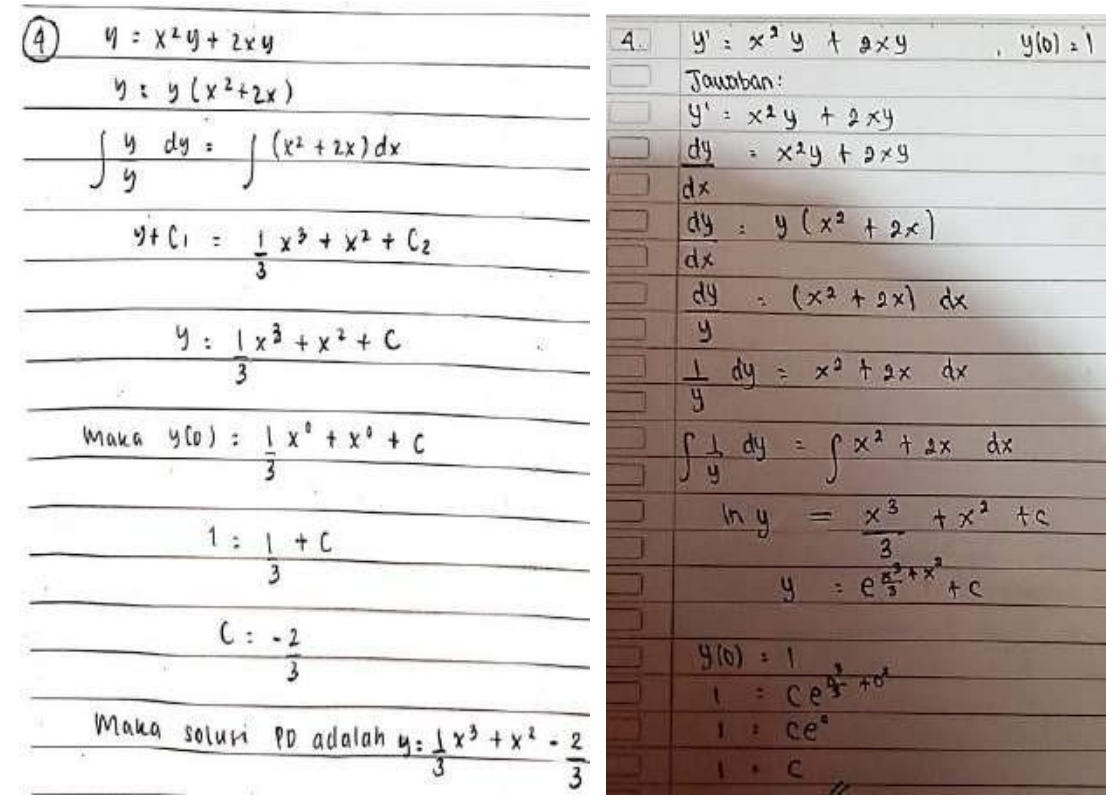

Gambar 9. Hasil dari subjek FIK dan FIL

\section{Mengembangkan Syarat Perlu Atau Syarat Cukup Suatu Konsep}
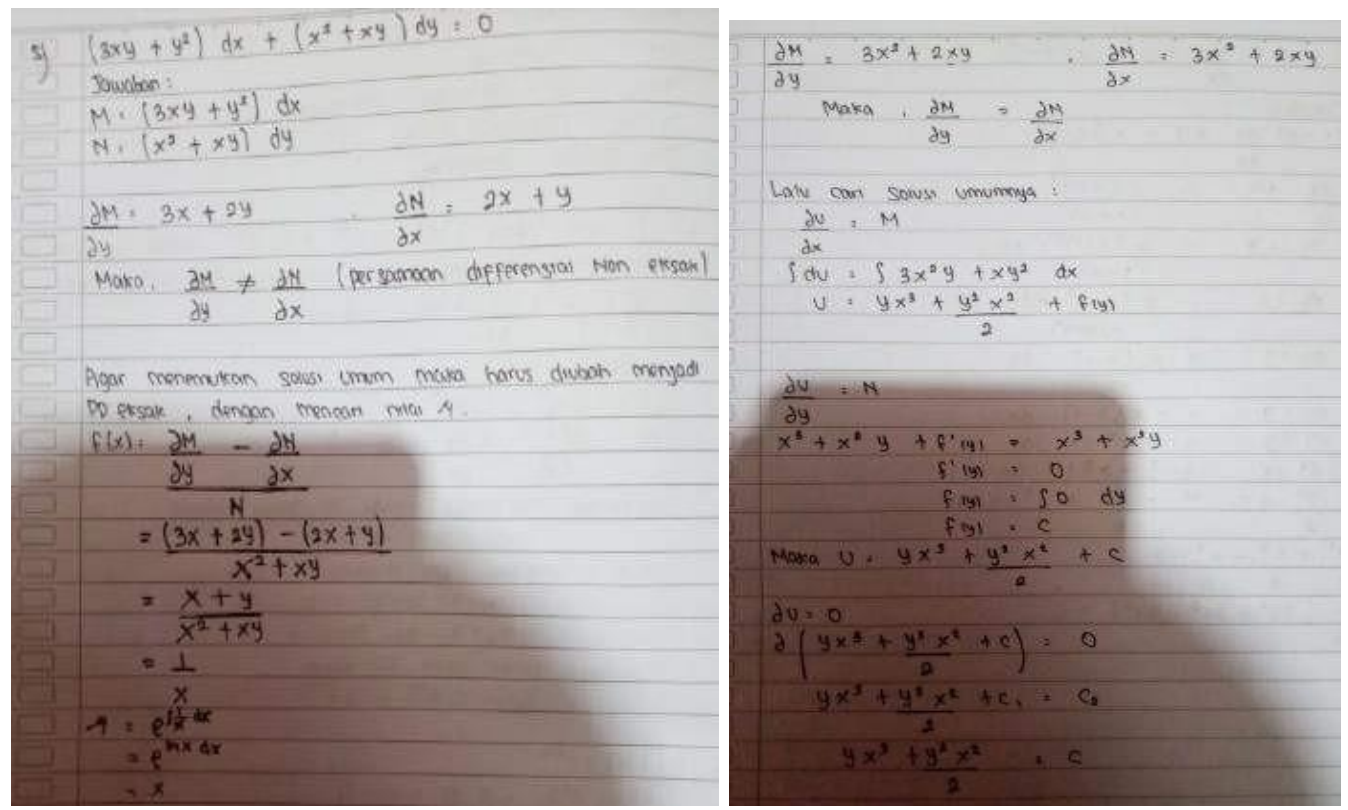

Gambar 10. Hasil dari subjek FIL

Berdasarkan gambar 10. Subjek FIL sudah benar dalam tahap menentukan PD eksak namun subjek FIL dalam tahap lanjutnya yaitu tahap menggunakan faktor integrasi dimana faktor integrasi digunakan untuk mencari solusi umum bagi PD bukan eksak menjadi PD eksak sudah tepat. 


\section{Menggunakan, Memanfaatkan, dan Memilih Prosedur Atau Operasi Tertentu}

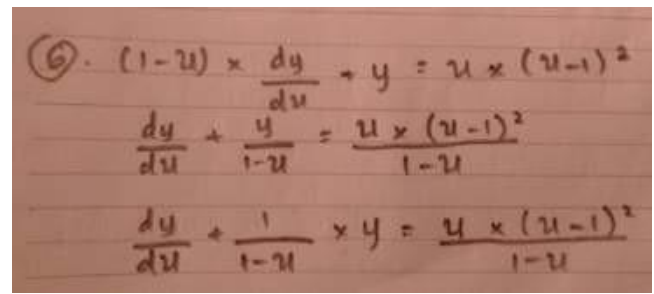

Gambar 11. Hasil dari subjek FDK dan FDL

Berdasarkan pada gambar 11. subjek FDK dan FDL belum mampu menggunakan, memanfaatkan, dan memilih prosedur atau operasi tertentu untuk mencari penyelesaian umum persamaan diferensial. Dimana subjek FDK dan FDL tidak mengetahui jenis dari persamaan diferensial tersebut.
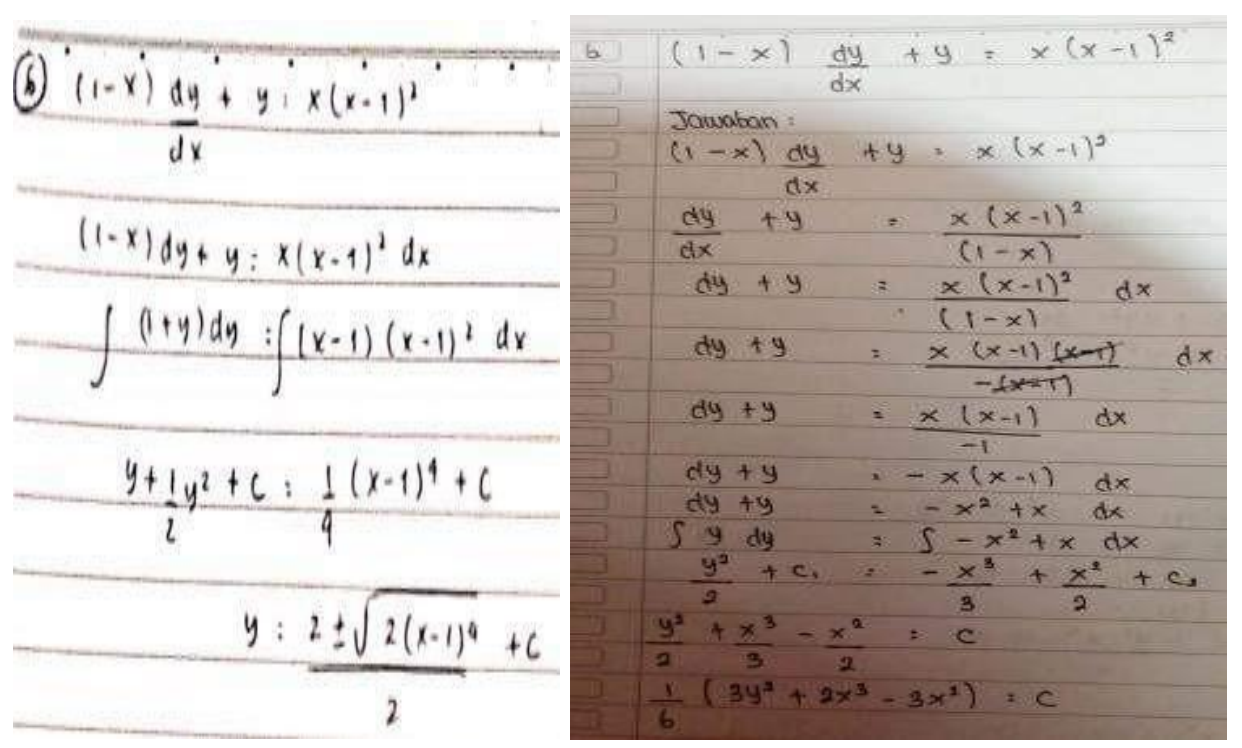

Gambar 12. Hasil dari subjek FIK dan FIL

Berdasarkan pada gambar 12. Subjek FIK dan FIL belum mampu untuk mencari penyelesaian umum persamaan diferensial. Dimana sama halnya dengan subjek FDK dan FDL dimana tidak mengetahui jenis dari persamaan diferensial dan masih bingung untuk menggunakan langkah awalnya yaitu ketika memisahkan variabelnya tersebut sehingga dalam mencari solusi penyelesaian persamaan diferensialnya masih belum tepat. 


\section{Mengaplikasikan Konsep atau Algoritma Pemecahan Masalah}

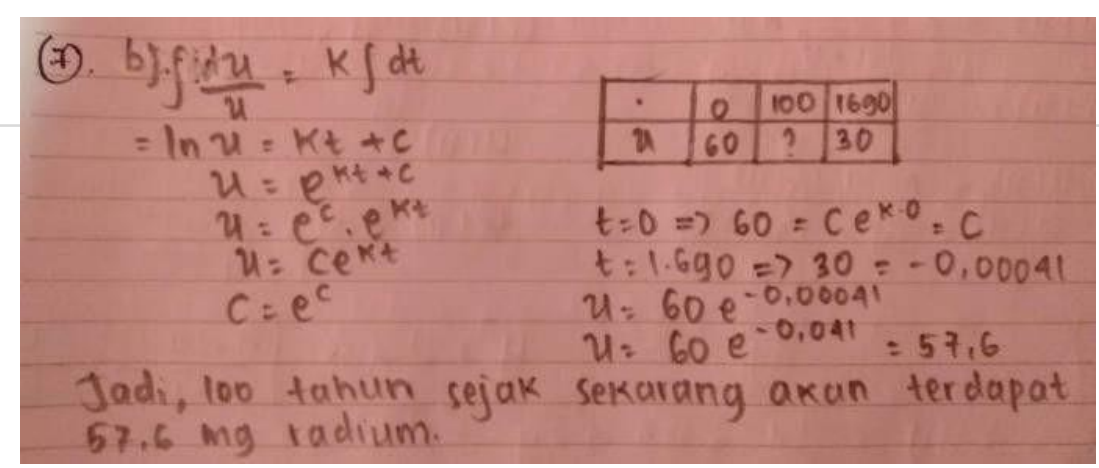

Gambar 13. Hasil dari subjek FDK dan FIK

Berdasarkan pada gambar 13. Subjek FDK dan FIL sudah mampu untuk menyelesaikan soal terkait pengaplikasian konsep persamaan diferensial dilihat dari hasil jawaban $7 \mathrm{~b}$ dimana dalam mengerjakan prosesnya FDK dan FIL menggunakan cara yang tepat untuk menyelesaikan soal yang berkaitan dengan penerapan persamaan diferensial. Bentuk grafik dari perbandingan persentase masingmasing indikator sebagai berikut.

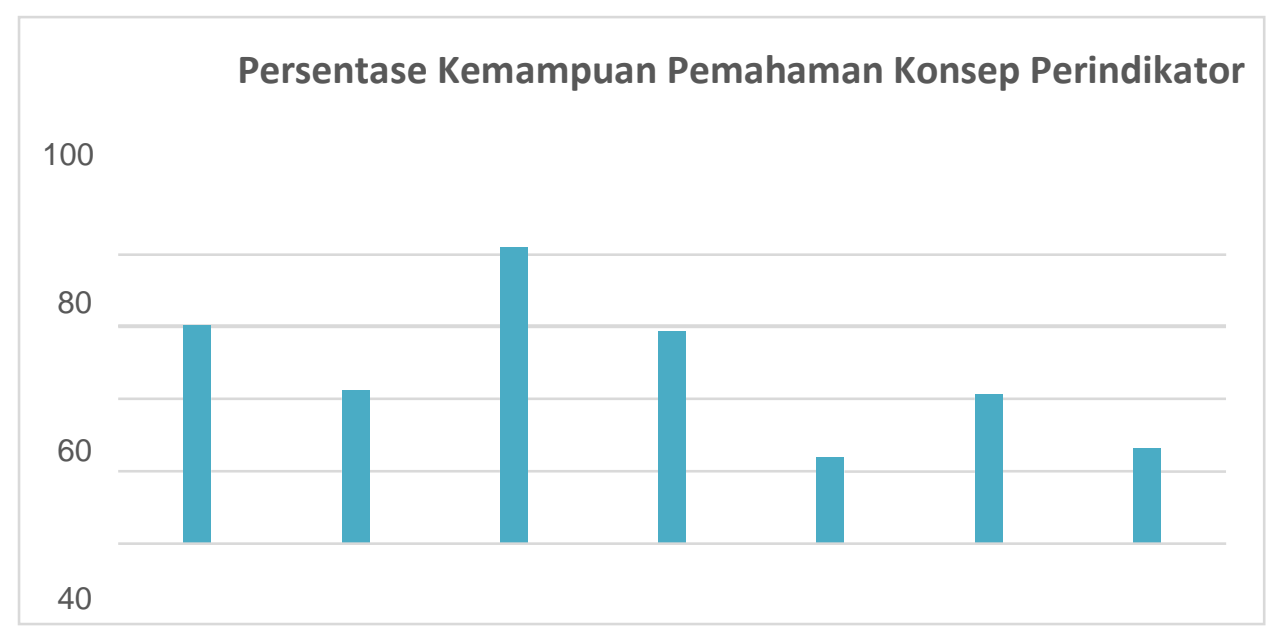

Adapun hasil tes kemampuan pemahaman konsep perindikator dapat dilihat pada tabel 6 berdasarkan interpretasi persentase kemampuan pemahaman konsep matematis (Kartika, 2018).

Tabel 6. Interpretasi Persentase Kemampuan Pemahaman Konsep Matematis

\begin{tabular}{|l|l|l|l|l|}
\hline Indikator & Rata-rata skor & Skor Maks & Persentase & Kategori \\
\hline I1 & 12,08 & 20 & 60,4 & Cukup baik \\
\hline I2 & 8,50 & 20 & 42,5 & Rendah \\
\hline I3 & 8,22 & 10 & 82,2 & Baik \\
\hline I4 & 5,89 & 10 & 58,9 & Cukup baik \\
\hline I5 & 2,39 & 10 & 23,9 & Sangat rendah \\
\hline I6 & 4,14 & 10 & 41,4 & Rendah \\
\hline I7 & 5,28 & 20 & 26,4 & Sangat rendah \\
\hline
\end{tabular}

Berdasarkan tabel 6. Kemampuan pemahaman konsep mahasiswa dalam menyelesaikan soal persamaan 
diferensial dilihat dari perindikatornya dimana mahasiswa sudah dalam kategori baik untuk indikator I1 , I3 dan I4 . sedangkan untuk indikator I2, I5, I6 dan I7 masih dalam kategori rendah.

Dalam pemahaman konsep matematis pada mata kuliah persamaan diferensial menurut responden kesulitan yang dialami dipengaruhi pemberian materi yang dilakukan secara daring dikarenakan Covid19. Keterbatasan pembelajaran yang dilaksanakan secara daring belum secara optimal sehingga konsep yang diajarkan masih banyak yang mereka belum pahami. Seperti salah satunya dalam membedakan jenisjenis persamaan diferensial, bahwasanya pengetahuan awal sangat penting dalam kelancaran proses perkuliahan. Untuk mengasah kemampuan pemahaman konsep matematis mahasiswa, dosen dapat membiasakan pemberikan latihan-latihan soal dalam setiap perkuliahan, mengaplikasikan konsep ke dalam pemecahan masalah serta pengetahuan awal sebagai konsep dasar pemahaman konsep matematis.

\section{KESIMPULAN}

Berdasarkan hasil penelitian ini disimpulkan bahwa kemampuan pemahaman konsep dari 36 mahasiswa dalam menyelesaikan soal persamaan diferensial ditinjau dari gaya kognitifnya secara keseluruhan 46,50\% dimana masih tergolong rendah. Dalam tingkat pemahaman konsepnya, kategori tinggi $25 \%$, kategori sedang $61,11 \%$ dan kategori rendah 13,89\%. Jika dilihat perindikator presentase pencapaian yang sudah mencapai baik untuk indikator I1, I3 dan I4 dan indikator I2, I5, I6 dan I7 masih dalam kategori rendah. Sedangkan pada gaya kognitif mahasiswa yang memiliki gaya kognitif field independent cenderung memiliki kemampuan lebih baik dibandingkan dengan mahasiswa yang memiliki gaya kognitif field dependent. Kemampuan pemahaman konsep kategori tinggi terdapat pada gaya kognitif FI baik FIK maupun FIL, kategori sedang dan rendah dimiliki gaya kognitif FIL sampai FDL.

\section{REFERENSI}

Andriyani, A., \& Ratu, N. (2018). Soal Cerita Pada Materi Program Linear Ditinjau Dari Gaya Kognitif Siswa. Jurnal Pendidikan Berkarakter, 1(1), 16-22.

Aydin Ceran, S., \& Ates, S. (2020). Conceptual understanding levels of students with different cognitive styles: An evaluation in terms of different measurement techniques. Eurasian Journal of Educational Research, 2020(88), 149-178. https://doi.org/10.14689/ejer.2020.88.7

Dewi, I. R. S., Chandra, T. D., \& Susanto, H. (2019). Proses Berpikir Mahasiswa Field Dependent Berdasarkan Kerangka Berpikir Mason. Jurnal Pendidikan, 4(7), 960-970.

Gusmania, Y., \& Agustyaningrum, N. (2020). Analisis Pemahaman Konsep Matematis Mahasiswa pada Mata Kuliah Trigonometri. Jurnal Gantang, 5(2), 123-132. https://doi.org/10.31629/jg.v5i2.2493

Haswati, D., \& Dian Nopitasari. (2019). Implementasi Bahan Ajar Persamaan Diferensial dengan Metode Guided Discovery Berbantuan Software Mathematica untuk Meningkatkan Pemahaman Konsep. Jurnal Gantang, 4(2), 97-102. https://doi.org/10.31629/jg.v4i2.1358 
Izzatin, M., Waluyo, S. B., Rochmad, \& Wardono. (2020). Students' cognitive style in mathematical thinking process. Journal of Physics: Conference Series, 1613(1). https://doi.org/10.1088/1742$6596 / 1613 / 1 / 012055$

Kartika, Y. (2018). Analisis kemampuan pemahaman konsep matematis peserta didik kelas vii SMP pada materi bentuk aljabar. Jurnal Pendidikan Tambusai, 2(4), 777-785.

Sihombing, S. C., \& Dahlia, A. (2018). Penyelesaian Persamaan Diferensial Linier Orde 1 dan 2 disertai Nilai Awal dengan Menggunakan Metode Runge Kutta Orde Lima Butcher dan Felhberg (RKF45). Jurnal Matematika Integratif, 14(1), 51. https://doi.org/10.24198/jmi.v14.n1.15953.51-60

Suningsih, A., \& Nopitasari, D. (2020). Mathematical Problem-Solving Ability in Differential Equation. 1(1), 37-40. https://doi.org/10.11594/baerj.01.01.05

Umah, U., \& Vitantri, C. A. (2019). Representasi Visual Matematis Mahasiswa Dalam Memodelkan Kejadian Dinamis Ditinjau Dari Perbedaan Gaya Kognitif Dan Jenis Kelamin. FIBONACCI: Jurnal Pendidikan Matematika Dan Matematika, 5(1), 87. https://doi.org/10.24853/fbc.5.1.87-96

Utami, A. D., Zainudin, M., \& Anggraini, L. (2020). Perubahan Konseptual Siswa Dalam Memahami Konsep Fungsi Ditinjau Dari Gaya Kognitif Field Dependent Dan Field Independent Dalam Pembelajaran Daring. Educatif: Journal of Education Research, 2(4), 1-16. http://pub.mykreatif.com/index.php/educatif/article/view/23

Utari, R. S., \& Utami, A. (2019). Kemampuan Pemahaman Konsep Mahasiswa Dalam Mengidentifikasi Penyelesaian Soal Integral Tak Tentu Dan Tentu. Jurnal Pendidikan Matematika, 14(1), 39-50. https://doi.org/10.22342/jpm.14.1.6820.39-50

Wulandari, Y. S., \& Muhandar, D. R. (2019). Identifikasi Kemampuan Pemahaman Konsep terhadap Gaya Kognitif Siswa SMP dengan Materi Kubus dan Balok. Prosiding Sesiomadika: Seminar Nasional Matematika Dan Pendidikan Matematika Universitas Singaperbangsa Karawang, 208-227.

Yin, Y. (2020). Analysis of the Differences between Field-Independence and Field-Dependence in Junior High School English Teaching. 8, 38-45. 